\title{
Human hair sutures in ophthalmic surgery
}

\author{
G. G. SOOD, D. K. SEN, AND L. D. SOTA \\ Department of Ophthalmology, Maulana Azad Medical College, New Delhi, India
}

Human hair having been suggested as a possible suture material (Leigh, ig66), we have examined the practicability of its use in ophthalmic surgery since it is so freely available and easily sterilized.

\section{Material}

Hairs varying from 6 to 12 in. in length were obtained mostly from women and in some cases from Sikh male members of the department. The hairs selected, after brittle, coarse, or extremely thin hairs had been discarded, were cleaned with 2 per cent. cetavlon, washed in water, wrapped around rubber tubing about 3 in. long to minimize curling, put into a wide-mouthed bottle, and autoclaved for 20 minutes.

\section{Methods of use}

\section{(1) Cataract Surgery}

A total of 100 cases was operated upon, the number of sutures applied varying from one to five (Table I). During the operation the suture ends were kept in place on the face towel by moist cotton swabs. Surgical knots were tied after the operation, and the free ends were cut very short with spring scissors.

Table I Cataract surgery

\begin{tabular}{|c|c|c|c|c|c|c|}
\hline \multirow{2}{*}{$\begin{array}{l}\text { Type of suture } \\
\text { (post-placed) }\end{array}$} & \multicolumn{5}{|c|}{ No. of sutures } & \multirow{2}{*}{ Total } \\
\hline & One & Troo & Three & Four & Five & \\
\hline $\begin{array}{l}\text { Corneo-scleral } \\
\text { Corneo-corneal } \\
\text { Sclero-scleral }\end{array}$ & $\frac{4^{2}}{-}$ & $\begin{array}{r}20 \\
4 \\
3\end{array}$ & $\begin{array}{r}14 \\
2 \\
3\end{array}$ & $\begin{array}{l}4 \\
3 \\
2\end{array}$ & $\begin{array}{l}3 \\
-\end{array}$ & $\begin{array}{r}83 \\
9 \\
8\end{array}$ \\
\hline Total & 42 & 27 & 19 & 9 & 3 & 100 \\
\hline
\end{tabular}

During the postoperative period conjunctival congestion was no more than would be expected. Wound closure was adequate in 98 cases, but in two a small knuckle of iris was found to prolapse between the stitches. The anterior chamber formed within 2 days in 97 cases; in three it remained shallow for a longer period and this was found to be associated with choroidal detachment. Wound leakage as the cause of a shallow chamber was excluded by the fluorescein test. Irritation in the eye was complained of in three cases; in these the suture ends were found to be in contact with the overlying palpebral conjunctiva. Relief was obtained by cutting the free ends shorter. Irritation was minimal when the ends were cut very short or buried under the conjunctiva. In no case 
did the knots slip. The sutures were removed on the 12 th to 14 th day in eighty cases, and removal was easy because of the dark colour and smooth surface. In the other twenty cases the sutures were left buried for 18 months for long-term follow-up, and no untoward reaction or granuloma formation was noted.

\section{(2) Conjunctival wound repair}

Human hair was used for continuous or interrupted sutures in fifty cases after trephine, iridencleisis, squint, and enucleation operations (Table II).

Table II Other types of surgery

\begin{tabular}{|c|c|c|c|c|c|}
\hline \multirow{2}{*}{ Type of suture } & \multicolumn{4}{|l|}{ Operation } & \multirow{2}{*}{ Total } \\
\hline & Trephine & Iridencleisis & Squint & Enucleation & \\
\hline $\begin{array}{l}\text { Continuous } \\
\text { Interrupted }\end{array}$ & $\underline{5}$ & $\begin{array}{r}21 \\
3\end{array}$ & $\begin{array}{r}11 \\
5\end{array}$ & $\underline{5}$ & $\begin{array}{r}42 \\
8\end{array}$ \\
\hline Total & 5 & 24 & 16 & 5 & 50 \\
\hline
\end{tabular}

Foreign body sensation was minimal, and the eyes became quiet in a few days. The sutures were removed on the $5^{\text {th }}$ to $7^{\text {th }}$ day after surgery, and no injection or granuloma formation was noted. The closure of the conjunctival wounds was perfect.

\section{Discussion}

Among the various suture materials which have been recommended from time to time are silk (Halsted, I913), absorbable surgical gut (Hughes, Guy, and Romaine, 1944; Davis, I944), virgin silk (Hoppenbrouwers, I962), wire (Hofmann, I962), and rat-tail tendon (Pischel, I930; Larmi, I96I; Gopal, Gupta, and Gupta, 1968). Adhesive synthetic material has been used experimentally by Bloomfield, Barnert, and Kanter (1963).

Our good results with human hair were similar to those of Leigh (1966).

The advantages of using human hair are as follows:

(I) It is freely available and easily sterilized by autoclaving.

(2) It is very fine, the average diameter being $87.54 \mu$ or approximately ooo,ooo, so that it passes easily through the eye of the finest needle, and also passes smoothly through the tissues; it is therefore useful for post-placed sutures especially if vitreous leakage is threatened.

(3) It is strong enough to hold the tissues together, is flexible, and does not crack or fray.

(4) It is easily visible for handling and picking up during operations, but the knot produced is small and does not slip.

(5) The capillarity is negligible, so that there is little chance of introducing external infection, and as it is non-irritant it produces hardly any tissue reaction or scarring.

\section{Summary}

A method is described of preparing and sterilizing human hair for use as suture material in ocular surgery. The results of a trial in one hundred cases of cataract surgery and fifty cases of extraocular surgery are reported. 


\section{References}

BlOOMfield, s., BARNert, A. H., and KANTER, P. (1963) Amer. F. Ophthal., 55, 946 DAVIS, F. A. (1944) Arch. Ophthal. (Chicago), 31, 321

GOPAL, H., GUPTA, J. S., and GUPTA, s. D. (1968) Orient. Arch. Ophthal., 6, 72; 115

hALSTED, W. s. (1913) F. Amer. med. Ass., 60, I I 19

hofmann, H. (1962) Klin. Mbl. Augenheilk., 141, $4^{02}$

HOPPENBROUWERS, R. W. J. N. (I962) Ophthalmologica (Basel), 143, 109

hughes, W. L., GUY, L. P., and Romaine, H. H. (1944) Arch. Ophthal. (Chicago), 32, 362

LARMI, T. (1961) Acta ophthal. (Kbh.), Suppl. 63

LEIGH, A. G. (1966) “Corneal Transplantation”, p. i 17. Blackwell Scientific Publications, Oxford PISGHEL, K. (1930) "XIII Concilium Ophthalmologicum Amsterdam, 1929, Bericht", vol. 2, p. 7 10 